\title{
国際委員 会
}

\section{（委員長）都築正和,（委員）池田卓也, 荻野和郎}

松本謙一, 三浦哲夫

\section{初期段階について}

国際委員会は1985年度に国際部として誕生し たので，その歴史は各部の中では比較的新しい ものに属する。

しかし，学会の国際的活動は，それ以前から もある程度行なわれてきた。具体例として，先 ずAAMI との関係の初期の実例を挙げると,實 川佐太郎名誉会員がAAMI の会員(日本人として 最初にはられてから，第二のメンバーは市河鴻 一理事であった。

年次大会 (AAMI) に医科器械学会関係者が出 席したのは，1974年であった。この年から現国 際委員長, 都築正和は毎年出席し, 演題を発表 してきな。

1976年の第51回日本医科器械学会大会 (石川浩 一大会長)では, 当時の AAMI 会長, ラウフマン 教授を招待講演に招き，医療機器の基準設定に 関する当時の, 最新の米国の状況について解説 をし，会員の意識改革に大きな貢献をしていた だいた。

\section{その後の国際関係の発展}

(以下，箇条書さで列挙)

1) AAMI との関係

*会員数, 発表演題数の増加

* AAMI 年次大会の際に夕食会, 次いで昼食会 を毎年行なって, AAMI 幹部との交流に努めて いる。

*カフマン政子氏を米国駐在員に任命

* AAMI 出版物の専売権, 翻訳権を獲得
* 第66回大会 (松本謙一大会長) には，当時の AAMI 会長，M. Levin 氏，専務理事 M. Miller 氏が始めて来日した，M. Levin 会長は，フォー ラム II, 医療機器産業の将来展望一21世紀はバ ラ色かーで，「医療情報システムのトレンド」と 題した講演を行なった。

*交流は一方通行から，やや相互通行に一しか

し末だに不十分と思われる。

* ICCのメンバーとして加盟

2) AAMI 以外との国際交流 *医療先進国一米国 FDA, HIMA, HIDA な゙ との医療機器関係問題についての検討に参加

3 ）医療機器をめぐる国際関係にも参加 *グローバル国際医療機器会議協賛団体として 参加

*世界における日本の地位が認識されてきた

\section{今後の問題点と光の対処法}

1) AAMI との相互協力関係を継続する

2 ) 米国, 欧州 (EC) の医療機器関係機関 $と$ の連 絡協議

3 ) NIES との関係を検討し, 進展させる

4）発展途上国との協力を促進寸る

5）その他

\section{用 語 解 説}

AAMI: Association for the Advancement of Medical Instrumentaion

米国医科器械学会 (米国医用機器振與協会) : Washington D. C.近くに本部を持ち, 日本医科器械 学会と同様な組織と内容を持って活動してきた。 
最近では, 特にFDA との関連を深め, 医用機器 の基準，許認可，保守管理なぞについて積極的 に活躍しょうとしている。

ICC: International Certification Commission: AAMIは，米国におけるCE (Clinical Enginerr), BMET (Biomedical Equipment

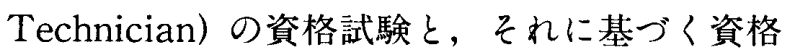
認定を行なっているが，この内容と業務を国際 的に拡大することを目的としている委員会のこ とである. 本年, 日本医科器械学会もそのメン バーとして加盟が承認された。

FDA: Food and Drug Administration: 米国 の厚生省 (Department of Health and Human Services-HHS)の一部局. わが国の厚生省薬務局 に相当する．初期には食品衛生と薬品の許認可 事務を主な業務としていたが，最近では医用機 器に関する業務も増加し, Dept. of Medical Devices and Radiological Health が独立した 部局として活躍するようになった。

HIMA: The Health Indutry Manifacturers Association：全米健康産業工業協会, 略称 " 匕 $\nabla^{\prime \prime}$
大型医療機器から医療材料, 体外診断薬, 医 療情報システムにいたるまでの約 300 社のメーカ 一からなるメバーで構成され，年間予算約 10 億円，50名の事務局スタッフを有寸る全米有数 の関連団体である。

現在の会長会社は J \& J, President は Magazine 氏, Vice President は Roginsky 氏, 本部 は Washington, D. C.

HIDA: The Health Industry Distributers Association, 全米健康産業流通協会. 略称 “八 イダ"

創立は1902年，1981年に協会名をそれまでの ASTAC (全米外科器械協会) から現在の「ヘルス・ ケアー」を入れた名称に変え, M活動分野も医 療器械から在宅医療にまで広げて以来, 飛躍的 な発展を遂げた，会員数も約700社にのぼり，年 間予算は約 5 億円，事務局スタッフも20数名を 持っている。米国で唯一の医療品の総合セール ス訓練を行なう「販売認定制度」も有する。本 部は Washington, D. C.で現在の President は Stoper 氏である。
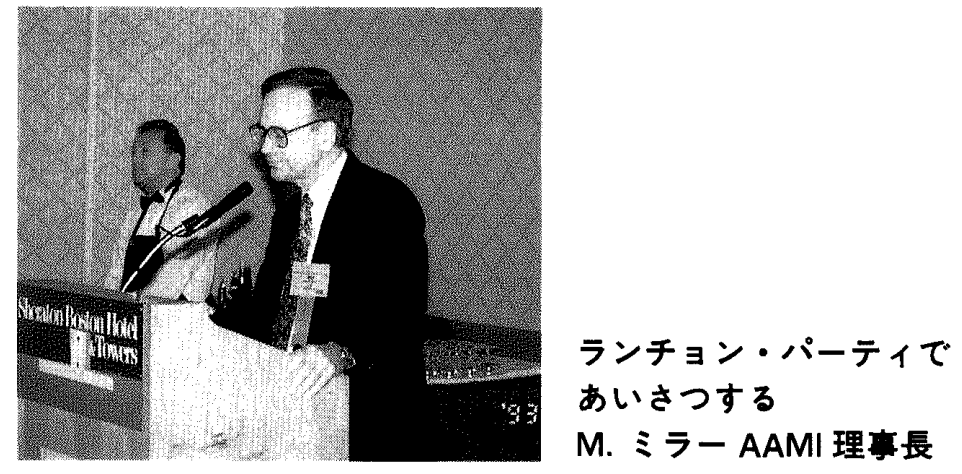

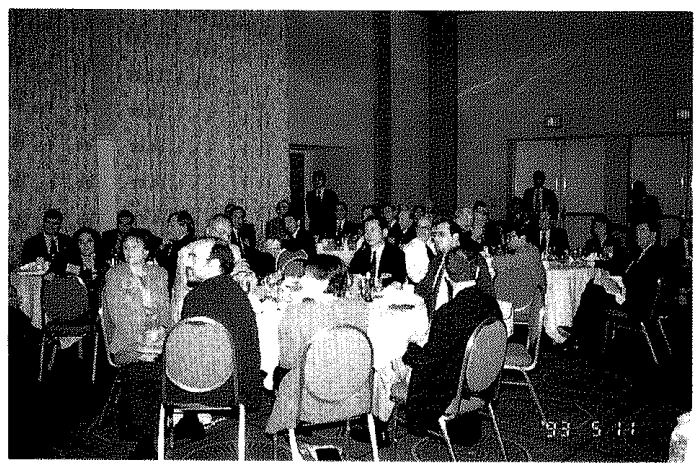

MISJ, AAMI ランチョン・パーティ

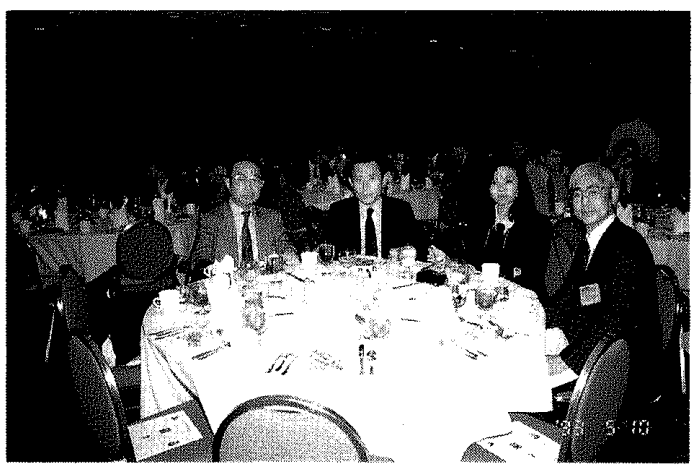

$A A M I$ 年次大会午養会 